\title{
BRCA1-A Complex Subunit RAP80
}

National Cancer Institute

\section{Source}

National Cancer Institute. BRCA1-A Complex Subunit RAP80. NCI Thesaurus. Code C124100.

BRCA1-A complex subunit RAP80 (719 aa, $~ 80 \mathrm{kDa}$ ) is encoded by the human UIMC1 gene. This protein is involved in the recognition of damaged DNA. 